\title{
The higher exercise intensity and the presence of allele I of ACE gene elicit a higher post-exercise blood pressure reduction and nitric oxide release in elderly women: an experimental study
}

Hugo AP Santana ${ }^{1,2}$, Sérgio R Moreira ${ }^{3}$, Willson B Neto ${ }^{1}$, Carla B Silva ${ }^{1,4}$, Marcelo M Sales ${ }^{1}$, Vanessa N Oliveira ${ }^{6}$, Ricardo Y Asano ${ }^{1,5^{*}}$, Foued S Espíndola ${ }^{6}$, Otávio T Nóbrega ${ }^{7}$, Carmen SG Campbell ${ }^{1}$ and Herbert G Simões ${ }^{1+}$

\begin{abstract}
Background: The absence of the I allele of the angiotensin converting enzyme (ACE) gene has been associated with higher levels of circulating ACE, lower nitric oxide (NO) release and hypertension. The purposes of this study were to analyze the post-exercise salivary nitrite $\left(\mathrm{NO}_{2}{ }^{-}\right)$and blood pressure (BP) responses to different exercise intensities in elderly women divided according to their ACE genotype.

Methods: Participants $(n=30 ; 1 / / I D=20$ and $D D=10)$ underwent three experimental sessions: incremental test IT (15 watts workload increase/3 min) until exhaustion; 20 min exercise $90 \%$ anaerobic threshold (90\% AT); and 20 min control session without exercise. Volunteers had their $\mathrm{BP}$ and $\mathrm{NO}_{2}{ }^{-}$measured before and after experimental sessions.

Results: Despite both intensities showed protective effect on preventing the increase of BP during post-exercise recovery compared to control, post-exercise hypotension and increased $\mathrm{NO}_{2}{ }^{-}$release was observed only for carriers of the I allele $(p<0.05)$.
\end{abstract}

Conclusion: Genotypes of the ACE gene may exert a role in post-exercise NO release and BP response.

\section{Background}

The systemic arterial hypertension (SAH) has committed about two thirds of elderly population in several countries [1,2]. Being considered a cardiovascular risk factor [3] that may be associated with endothelial dysfunction and thus with a low endothelial dependent vasodilatation $[4,5]$.

The treatment of SAH includes pharmacological therapy and lifestyle changes, such as physical activity enrollment and nutritional habits re-education [6]. Among cardiovascular benefits of exercise, the postexercise blood pressure reduction has been considered an important tool for blood pressure (BP) control [7-15]. The protective effect of exercise in lowering

\footnotetext{
* Correspondence: ricardokiu@ig.com.br

† Contributed equally

'Programa de Pós-graduação em Educação Física e Saúde, Universidade

Católica de Brasília - UCB, Brasília-DF, Brazil

Full list of author information is available at the end of the article
}

blood pressure may be mainly due vasodilatation substances induced vascular resistance reduction after exercise [9].

During physical exercise the increased blood flux lead to mechanical vessel stress and thus an endothelial NO release [16]. The NO is involved with vascular tonus regulation [17] and its release has been associated to post-exercise BP reduction (e.g. post-exercise hypotension - PEH), which may even be influenced by genetic characteristics [18].

Hypertensive people would benefit from PEH as a non-pharmacological adjunct to the SAH treatment. However, Hagberg et al. [19] highlighted that approximately $25 \%$ of the hypertensive individuals do not present PEH, what could be partially explained by genetic variations.

Studies about the insertion/deletion (I/D) polymorphism of angiotensin converting enzyme (ACE) and its 
associations to functional, metabolic and cardiovascular phenotypes have been documented [20-22], including SAH $[10,23]$. The absence of I allele of ACE gene (e.g. individuals $\mathrm{D} / \mathrm{D}$ ) has been associated with higher levels of circulating ACE [24-26] leading to an increased angiotensin II (ANG II) concentration, reduced bioavailability of bradykinin and thus to a lower NO release $[27,28]$.

We hypothesized that in respect to ACE gene, the D/ $\mathrm{D}$ carriers would present lower NO release during exercise and thus both lower vasodilatation and reduced post-exercise blood pressure reduction than those with the I allele. Furthermore, once the endothelial release of $\mathrm{NO}$ is dependent on both metabolic and mechanical stress (shear stress) [16], it was also hypothesized that aerobic exercise of a greater intensity would result in a higher NO release and thus to elicit a greater post-exercise BP reduction in elderly hypertensive women.

Therefore, the purposes of this study were to analyze the post-exercise $\mathrm{NO}$ and blood pressure responses to different exercise intensities in elderly women with or without the I allele of ACE gene, as well as to investigate if the NO release and post-exercise hypotension in this population would be influenced by of the I/D polymorphism of ACE gene. Due to factors such as age and gender affect blood pressure responses, this report poses a contribution by standardizing these variables in our sample.

\section{Methods}

\section{Participants}

In the initial phase of this study 268 elderly women $(\leq 60$ years-old) clinically diagnosed with hypertension were genotyped for the I/D polymorphism of ACE gene. The diagnosis of hypertension in this sample was performed in 2005 and confirmed in 2006/2007 at the medical department of the University according to IV Brazilian Hypertension Guidelines (2006) [29] following procedures previously described by Moraes et al. (2008) [30]. From these initial volunteers, thirty elderly women $(70.5$ \pm 6.0 years, $60.4 \pm 8.5 \mathrm{~kg}, 153.3 \pm 6.3 \mathrm{~cm}$ and $25.7 \pm 3.0$ $\mathrm{kg} / \mathrm{m}^{2}$ ) diagnosed with mild hypertension and whose pharmacotherapy consisted only on diuretics as hydrochlorothiazide and indapamide (not interfering with the RAS) were selected to enrolled in a local program for SAH treatment which included regular physical activity and recommendation of a balanced food intake.

After recruitment, participants were allocated into two different groups according to the presence (II and ID) or absence (DD) of 287 pairs of base. Participants of both groups (II/ID and DD) randomly underwent to three experimental test sessions on non-consecutive days, inter a spread with at least 48-hours apart. After giving a written consent, each volunteer was first submitted to a resting electrocardiogram, and exercise tests were performed under cardiologist's supervision. The study was approved by the local ethical committee (process $n^{\circ}$ CEP/UCB 63/2008).

\section{General Procedures}

All 268 women had a blood collection for the determination of their I/D polymorphism of ACE gene. After that, 30 volunteers were selected according to their availability to underwent to testing protocol, their ACE genotype (individuals with and without the I allele of $\mathrm{ACE}$ ) as well as considering the exclusion criteria (e.g. use of medicines that would interfere on RAS). Before each experimental session, all volunteers remained on resting for 20 minutes, and blood pressure (BP) was measured every five minutes, being the average considered the resting BP. Experimental design consisted in an incremental test session, one session at $90 \%$ of anaerobic threshold and another session without exercise (control session). After all sessions, the volunteers remained in the laboratory for recovery during one hour. In this time span, the post-exercise BP was measured every 15 min, and the mean of these measures was considered. $\mathrm{NO}$ was inferred from the measurement of nitrite $\left(\mathrm{NO}_{2}{ }^{-}\right.$ ) in saliva [31-34]. For this analysis, saliva was collected during resting before exercise (or control) in all testing days (PRE), immediately after exercise (IAE) and concomitantly to BP measurements throughout the recovery period. The saliva was collected through a cotton swab.

\section{ACE Genotyping}

Total DNA was isolated from peripheral blood according to standard procedures. The insertion(I)/deletion(D) polymorphism in the human ACE gene (rs4646994) was determined by inspection of the electrophoretic profile of polymerase chain-reaction (PCR) products, and performed as described by Marre et al. with modifications [34]. Either the $490 \mathrm{bp}$ (I allele) or the $190 \mathrm{bp}$ (D allele) products were amplified using primers: 5'-CTGCAGACCACTCCCATCCTTTCT-3' and 5'-GATGTGGCCATCACATTCGTCAGAT-3', which flank the polymorphic site. Reaction tubes contained $100 \mathrm{ng}$ DNA, $10 \mathrm{mmol} / \mathrm{L}$ Tris-HClpH8.3,75 mmol/L KCl, $3.5 \mathrm{mmol} / \mathrm{L} \mathrm{MgCl} 2$, 0,2 $\mathrm{mmol} / \mathrm{L} \mathrm{dNTP}, 20 \mathrm{pmol}$ of each primer, $0.5 \mu \mathrm{g}$ of purified chicken albumin and $1 \mathrm{U}$ of Taq DNA polymerase (Phoneutria $^{\circledR}$, Minas Gerais, Brazil) in a final volume of $25 \mu \mathrm{L}$. After $1 \mathrm{~min}$ of hot start at $80{ }^{\circ} \mathrm{C}$ and an initial denaturation for $2 \mathrm{~min}$ at $94{ }^{\circ} \mathrm{C}$, the amplifications were done for 30 cycles of $40 \mathrm{~s}$ at $94{ }^{\circ} \mathrm{C}, 45 \mathrm{~s}$ at $64{ }^{\circ} \mathrm{C}$ and 50 $\mathrm{s}$ at $72{ }^{\circ} \mathrm{C}$ followed by a final $5 \mathrm{~min}$ extension at $72{ }^{\circ} \mathrm{C}$. Inspection of DD subjects was carried out using oligonucleotides (5'-TGGGACCACAGCGCCCGCCACTAC3' and 5'-TCGCCAGCCCTCCCATGCCCATAA-3') specific to amplify a $335 \mathrm{bp}$ fragment of the insertion sequence. In brief, DNA was amplified for 30 cycles 
with denaturation at $92{ }^{\circ} \mathrm{C}$ for $40 \mathrm{~s}$, annealing at $63{ }^{\circ} \mathrm{C}$ for $40 \mathrm{~s}$, and extension at $72{ }^{\circ} \mathrm{C}$ for $40 \mathrm{~s}$. All PCR products were separated by electrophoresis on $2 \%$ agarose gels containing ethidium bromide at $50 \mu \mathrm{g} / \mathrm{ml}$, visualized by using CCD camera (Vilber Lourmat ${ }^{\mathbb{B}}$, Eberhardzell, Deutschland), examined using the gel analysis software enclosed (Photo Capt 1D), and confirmed by visual inspection.

\section{Incremental Test and Anaerobic Threshold (AT) determination}

The volunteers performed a maximal incremental test (IT) in cycle ergometer (Lode Excalibur, Netherlands) that consisted in 1-min warm-up at 0 watts followed by a pace of linear, incremental gradient in 15 watts every 3 minutes stage. The test was terminated due volitional exhaustion, incapacity of maintaining $60 \mathrm{rpm}$ or if any cardiovascular-related risk was detected by cardiologist. In each stage of IT, a blood sample was withdrawn from earlobe to assess blood lactate concentration [Lac]. Measures of rate of perceived exertion (RPE) as well as ventilation (VE), oxygen uptake $\left(\mathrm{VO}_{2}\right)$ and carbon dioxide production $\left(\mathrm{VCO}_{2}\right)$ (Cortex Metamax, Leipzig, Germany) were performed at the end of each stage.

The AT intensity was determined by assessing the ventilatory threshold (disproportional increase in the ventilatory equivalent for oxygen $\left(\mathrm{VE} / \mathrm{VO}_{2}\right)$ in relation to ventilatory equivalent for dioxide carbon $\left(\mathrm{VE} / \mathrm{VCO}_{2}\right)$ and the [Lac] turnpoint (workload corresponding to deflection point where the concentration of blood lactate increased disproportionally). The AT was considered the mean workload (watts) between ventilatory and lactate thresholds.

\section{Sub-maximal constant load exercise test}

Participants underwent to a constant load exercise test at intensity corresponding to $90 \%$ AT. During the 20 min exercise at $90 \% \mathrm{AT}$, expired gases were measured continuously and the RPE were asked at the $10^{\text {th }}$ and at the end of exercise. This intensity was chosen due to benefits on blood pressure and cognitive performance observed in other studies in elderly individuals $[11,35]$.

\section{Control Session}

During control session the volunteers remained in resting for $20 \mathrm{~min}$ instead of exercising. However, all measurements were the same as those performed during a constant load exercise session.

\section{Measurements}

\section{Blood Lactate and Gases Analyses}

In the incremental test on cycle ergometer, blood samples were drawn and expired gases were collected during the last 20 seconds of each incremental stage.
The blood was collected in microcapillary heparinized tubes and deposited in microtubes containing $50 \mu \mathrm{L}$ of sodium fluoride (1\%) for [Lac] measurements through an electrochemical analyzer (YSI 2700, YSI, Inc., Yellow Springs, OH, USA). Expired gases were collected breath by breath (Cortex Metamax, Leipzig, Germany). For the $90 \%$ AT and CONT groups, blood collection occurred at the $10^{\text {th }}$ and $20^{\text {th }}$ minutes; however gas measurement occurred during the whole 20 min span.

Heart Rate, Rate of Perceived Exertion and Blood Pressure During the all sessions, the heart rate (HR) (Polar s810 $^{\circledR}$, Kempelle, Finland), a 15 point RPE scale [36] and blood pressure (BP) (Microlife BP3AC1-1, Berneck, Switzerland) were determined. All resting and post-exercise BP measurements were made according to the procedures of JNC 7 [2] on the participant's left arm while they were seated with their feet on the ground and arm resting comfortably at the level of the heart.

\section{NO Metabolic Measurement in saliva}

Saliva was collected with a cotton swab (Salivette Sarstedt ${ }^{\circledR}$, Nümbrecht, Germany) which was chewed for one minute. Then it was centrifuged according to the manufacture instructions and stored in $-20^{\circ} \mathrm{C}$ for latter analysis. Dosage of nitrite $\left(\mathrm{NO}_{2}{ }^{-}\right)$a $\mathrm{NO}$ metabolite [31-33] was done through the Griess' colorimetric method $^{22}$. Briefly, N-(1-naphthyl)-ethylenediamine (NED) $\left(\right.$ Sigma $^{\circledR}$ - Aldrich, St. Louis, USA) was prepared at $0.1 \%$, whereas sulfanilamide $\left(\operatorname{Sigma}^{\circledR}\right)$ at $1 \%$, both with phosphoric acid at $2.5 \%$ as diluent. Saliva $(50 \mu \mathrm{L})$ and the Griess' reagent $(50 \mu \mathrm{L})$ were mixed and placed in microplates. Absorbance was measured at $450 \mathrm{~nm}$, in Versamax tunable $^{\circledR}$ (Molecular Devices, Sunnyvale, California, USA), and sodium nitrite $\left(\mathrm{NaNO}_{2}{ }^{-}\right)$was used as a standard. The data were analyzed in the Microplate ${ }^{\circledR}$ software. Saliva samples of only 28 (II/ID - n $=18$, DD $\mathrm{n}=10$ ) elderly women were processed due technical problem in collecting procedures of two volunteers that unable to run the analyses.

\section{Statistical Analyses}

An exploratory analysis was used to verify data normality and then descriptive statistics were performed. Data are presented as means ( \pm standard deviation) for BP and means ( \pm standard error of mean) for $\mathrm{NO}_{2}{ }^{-}$. In addition, the delta variations (absolute variation from rest to post-exercise values) were calculated for comparison. Student's t-test and One-Way ANOVA for repeated measures were used to compare experimental sessions. The Tukey test was adopted as a post hoc to identify differences. The level of significance was set at $\mathrm{p} \leq 0.05$. 


\section{Results}

The general characteristics of the volunteers and power output, aerobic fitness, heart rate, metabolic variables and RPE results of IT and 90\%AT according to the genotypes of the investigated groups are presented on table 1.

The systolic blood pressure (SBP), diastolic blood pressure (DBP) and mean arterial pressure (MAP) are presented on table 2 as related to the studied ACE genotype groups. Since the data did not present any significant differences for the resting values $(P>0.05)$, the delta variation results (post-exercise values minus resting values) was also used to analyze variation among sessions.

During the post-exercise recovery from IT the SBP values (table 2) were significantly lower than pre-

Table 1 General characteristics and descriptive data of the studied groups of carriers or non-carriers of "I" allele of ACE gene $(n=30)$.

\begin{tabular}{|c|c|c|c|}
\hline & I/D-I/I & $\mathrm{D} / \mathrm{D}$ & $p$ \\
\hline $\mathrm{N}$ & $10 / 10$ & 10 & - \\
\hline Age (years) & $70.4 \pm 6.2$ & $70.6 \pm 5.8$ & 0.93 \\
\hline Weight (kg) & $60.6 \pm 8.4$ & $60.0 \pm 9.1$ & 0.86 \\
\hline Height $(\mathrm{cm})$ & $153.1 \pm 7.1$ & $153.7 \pm 4.7$ & 0.82 \\
\hline $\mathrm{BMI}\left(\mathrm{kg} \cdot \mathrm{m}^{-2}\right)$ & $25.9 \pm 3.0$ & $25.4 \pm 3.2$ & 0.70 \\
\hline \multicolumn{4}{|l|}{$\begin{array}{l}\text { Metabolic and Hemodynamic } \\
\text { Variables }\end{array}$} \\
\hline Glycaemia $\left(\mathrm{mg} \cdot \mathrm{dL}^{-1}\right)$ & $86.9 \pm 13.1$ & $79.6 \pm 17.1$ & 0.21 \\
\hline SBP IT rest $\left(\mathrm{mm} \cdot \mathrm{Hg}^{-1}\right)$ & $\begin{array}{c}129.0 \pm \\
17.0\end{array}$ & $\begin{array}{c}125.0 \pm \\
14.0\end{array}$ & 0.47 \\
\hline DBP IT rest $\left(\mathrm{mm} \cdot \mathrm{Hg}^{-1}\right)$ & $77.0 \pm 8.0$ & $77.0 \pm 7.0$ & 0.87 \\
\hline $\mathrm{NO}_{2}^{-}$rest $(\mu \mathrm{M})$ & $\begin{array}{l}294.4 \pm \\
176.5\end{array}$ & $\begin{array}{c}278.2 \pm \\
159.0\end{array}$ & 0.81 \\
\hline \multicolumn{4}{|c|}{ Performance data of IT and $90 \% A T$} \\
\hline Watts peak IT (Watts) & $62.3 \pm 21.4$ & $57.0 \pm 19.7$ & 0.52 \\
\hline Watts at AT (Watts) & $38.4 \pm 14.4$ & $39.6 \pm 14.8$ & 0.83 \\
\hline Watts at 90\%AT (Watts) & $34.5 \pm 13.0$ & $35.6 \pm 13.3$ & 0.83 \\
\hline $\mathrm{VO}_{2}$ peak IT $\left(\mathrm{mL} \cdot \mathrm{kg}^{-1} \cdot \mathrm{min}^{-1}\right)$ & $20.5 \pm 4.3$ & $20.1 \pm 3.0$ & 0.78 \\
\hline $\mathrm{VO}_{2}$ at $90 \% \mathrm{AT}\left(\mathrm{mL} \cdot \mathrm{kg}^{-1} \cdot \mathrm{min}^{-1}\right)$ & $14.8 \pm 2.3$ & $15.8 \pm 3.3$ & 0.37 \\
\hline HRpeak IT (bpm) & $\begin{array}{l}148.0 \pm \\
21.0\end{array}$ & $\begin{array}{l}142.7 \pm \\
19.6\end{array}$ & 0.51 \\
\hline HR at 90\%AT (bpm) & $\begin{array}{l}119.5 \pm \\
15.8\end{array}$ & $\begin{array}{l}116.8 \pm \\
17.6\end{array}$ & 0.68 \\
\hline [Lac] peak (mM) & $4.8 \pm 1.9$ & $4.4 \pm 1.4$ & 0.54 \\
\hline [Lac] 90\%AT (mM) & $3.0 \pm 1.1$ & $3.3 \pm 1.2$ & 0.42 \\
\hline RPE peak IT (Borg) & $17.6 \pm 1.5$ & $18.1 \pm 1.6$ & 0.41 \\
\hline RPE at $90 \%$ LA (Borg) & $13.2 \pm 2.0$ & $13.8 \pm 1.2$ & 0.42 \\
\hline $\begin{array}{l}\text { Diuretics Medication (\% of } \\
\text { volunteers) }\end{array}$ & 20.0 & 20.0 & - \\
\hline
\end{tabular}

I/D-I/I and D/D - angiotensin converting enzyme (ACE) genotype; BMI - body mass index, SBP - systolic blood pressure, DBP - diastolic blood pressure, $\mathrm{NO}_{2}{ }^{-}$ - nitrite concentration, VO2peak: peak oxygen consumption reached in IT; VO2: oxygen consumption; HRpeak: peak heart rate reached in IT; HR: heart rate; [Lac] peak: peak lactate concentration reached in IT; [Lac]: lactate concentration; RPE peak: peak rate of perceived exertion reached in IT; RPE: rate of perceived exertion. exercise resting for the II/ID group both for the IT and 90\%AT sessions. These variations when analyzed in delta were significantly lower $(\mathrm{p}<0.05)$ to control session and to D/D groups in the same circumstances. The DBP and MAP on the control sessions present differences $(p<0.05)$ or at least a trend to it $(p=0.06)$ for the $\mathrm{D} / \mathrm{D}$ group for $\mathrm{DBP}$, from the rest to $1 \mathrm{~h}$ Mean recovery time. The delta variation of MAP presented significant negative values for the IT and 90\%AT sessions being significant different $(\mathrm{p}<0.05)$ to the control delta variation.

The $\mathrm{NO}_{2}{ }^{-}$(table 3 ) presented a significantly higher (P $<0.01$ ) values immediately after experimental session at IT (IAE) and a trend to be higher $(\mathrm{P}=0.08)$ at the $90 \%$ AT session too (Figure 1) in comparison to resting on the group that presented the I allele of ACE gene.

The delta variation of $\mathrm{NO}_{2}{ }^{-}$presented significant differences $(\mathrm{p}<0.05)$ with a higher $\mathrm{NO}_{2}{ }^{-}$release after IT for the II/ID group when compared to DD group as shown in Figure 1.

\section{Discussion}

This study analyzed the BP responses after different exercise intensities and the $\mathrm{NO}_{2}{ }^{-}$release as related to ACE genotypes in elderly women. The main findings were that both the exercise intensity and the presence of I allele of ACE gene may interfere on $\mathrm{NO}_{2}^{-}$liberation and post-exercise hypotension $(\mathrm{PEH})$ occurrence in hypertensive elderly women. PEH occurred for the SBP among carriers of the I allele only. Also, those I carriers presented lowered post-exercise blood pressure levels in relation to the DD group. Despite the intensity of the exercise sessions, both intensities were effective for lowering the resting values of $\mathrm{BP}$ whereas these values increased in the control session, without exercise.

The fact that only elderly women that had the I allele presented PEH of SBP after both exercise sessions (table 2 ) is probably due to the fact that D/D homozygote presents almost twice as higher the angiotensin converting enzyme activity when compared to the insertion homozygote [24,25]. The role of ACE is mainly to convert angiotensin I to angiotensin II. This last action are related to an increased sympathetic tone induced arteriolar constriction and release of aldosterone from suprarenal cortex $[22,37,38]$ which, in turn acts in kidneys, leading to potassium excretion, salt reabsorption and water retention. All those effects may elevate the BP, and in theory would interfere in the post-exercise BP achievement.

Additionally, the fact that DD individuals present a higher circulating level of ACE [25] may lead to a higher activity of ANG II that may further blind the vasodilation induced by bradykinin [37] and thus influence the $B P$ values [22]. This mechanism causes a negative 
Table 2 Blood Pressure results at pre and post-sessions as well as the post-exercise delta variation in relation to preexercise resting for the ID/II and DD groups.

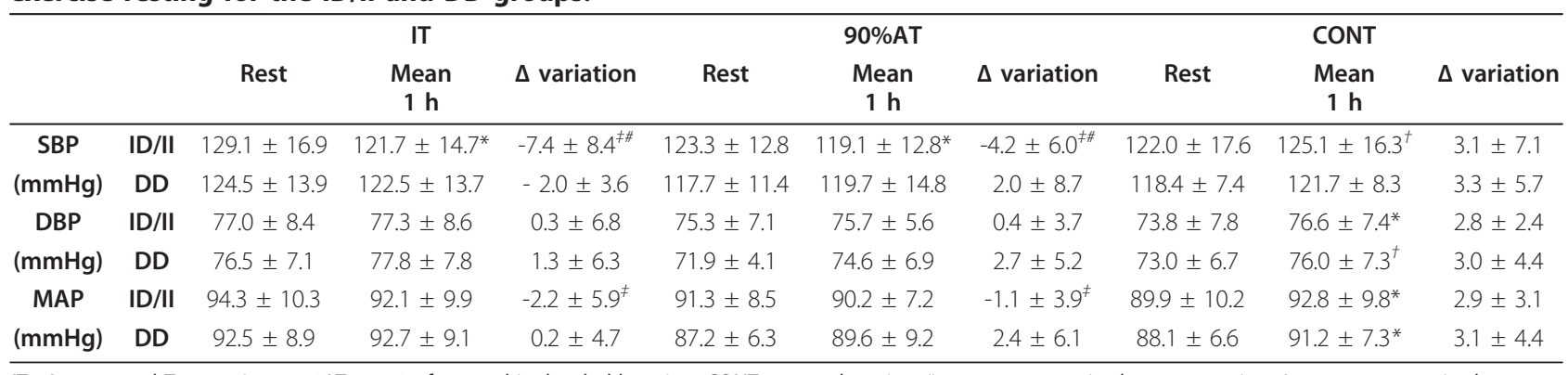

IT - Incremental Test session, 90\%AT - 90\% of anaerobic threshold session, CONT - control session. ${ }^{*} p<0.05$ to rest in the same session; tp $=0.06$ to rest in the same session; $\neq p<0.05$ to Cont in the same group, $\# p<0.05$ to $D / D$ in the situation.

impairment on the endothelial dependent dilation, once it reduces the bioavailability of NO [16] what, in turn, would be the reason of non significant post-exercise blood pressure reduction for the $\mathrm{D} / \mathrm{D}$ group in any experimental session of the present study.

The findings of PEH of SBP in present study, for the group that presented the I allele, were similar to others studies. Pescatello et al. (2007) [10] analyzed the BP response after high and low calcium ingestion and after two sessions of low and moderate exercise intensity, and verified in the intensity corresponding to $60 \% \mathrm{VO}_{2} \max$, the I allele carriers that had low calcium ingestion presented PEH of higher magnitude for the SBP. However, for the DBP no ACE genotypes interactions were found. For the present study, besides the main effect on SBP, the exercise also presented a protective effect on postexercise DBP and MAP despite the genetic profile compared to control (table 2).

Blanchard et al. (2006) [39] verified for $14 \mathrm{~h}$ the ambulatory BP in adult men at the same intensities studied by Pescatello et al. (2007) [10] and the results were contradictory to ours, presenting increases in the mean of $14 \mathrm{~h}$ in the SBP and DBP for all experimental sessions $\left(60 \% \mathrm{VO}_{2} \max , 40 \%\right.$ do $\mathrm{VO}_{2} \max$ and control) despite the genetic combinations of RAS, however the exercise sessions had benefits when compared to control. Moreover, they found benefits of post exercise SBP $14 \mathrm{~h}$ after light exercise session $\left(40 \% \mathrm{VO}_{2} \mathrm{max}\right)$ with lower values for the DD homozygote but not for the I allele group. These distinct results may be either related to gender differences, because some studies suggest that associations between BP and genotype DD of ACE gene are only significant in men showing some effect on the BP $[40,41]$, or to age differences, because in present study the sample was composed by elderly people, that presents different endothelial responses when compared to youngsters [42].

The BP increase in the control session can be partly explained from the waiting time (60 minutes) until the end of data collection procedures, that may have produced some degree of distress that may have contributed to the augmentation observed. Zimmerman \& Frohlich [43] related that acutely, stress episodes have been shown to increase blood pressure by increasing cardiac output and heart rate but without affecting peripheral resistance. In addition, even moderate stress has been found to increase levels of catecholamines, cortisol, vasopressin, endorphins and aldosterone, which may in part explain the increase in blood pressure. This may not have occurred in the experimental session (90\% AT) due to the protective effect of exercise in situations of acute stress, as observed by MacDonald et al. [44].

Furthermore, the increase in BP even with the nonsignificant of $\mathrm{NO}_{2}^{-}(\mathrm{p}>0.05)$ augmentation in the DD group may be due to overlap of complementary input signals, with a probable prevalence of humoral and neural mechanisms in blood pressure control. Studies [45-47] have reported that individuals carrying the DD genotype have higher levels and activity of the angiotensin converting enzyme (ACE), which therefore could result in a greater increase in blood pressure by increasing the conversion of angiotensin I to II, causing

Table 3 Nitrite $\left(\mathrm{NO}_{2}{ }^{-}\right)$concentrations in rest and immediately after experimental session in groups separated by ACE genotypes (ID/II - $n=18$; DD - $n=10$ ).

\begin{tabular}{cccccccc}
\hline & \multicolumn{2}{c}{ TI } & \multicolumn{2}{c}{ 90\%AT } & \multicolumn{2}{c}{ CONT } \\
& & Rest & IAE & Rest & IAE & Rest & IAE \\
\hline $\mathbf{N O}_{2}{ }^{-}(\mu \mathrm{M})$ & ID/II & $286.6 \pm 29.4$ & $401.3 \pm 52.8^{*}$ & $239.8 \pm 34.6$ & $337.5 \pm 63.8^{+}$ & $295.5 \pm 39.4$ & $292.9 \pm 44.9$ \\
& DD & $264.9 \pm 70.5$ & $282.9 \pm 63.8$ & $318.5 \pm 65.0$ & $341.2 \pm 93.6$ & $251.1 \pm 44.8$ & $293.0 \pm 94.2$ \\
\hline
\end{tabular}

IT - incremental test session, $90 \%$ AT - session at $90 \%$ of anaerobic threshold, CONT - control session, $\mathrm{NO}_{2}{ }^{-}$- nitrite, IAE - immediately after experimental session. ${ }^{*} p<0.01$ in relation to rest in the same session; ${ }^{t} p=0.08$ in relation to rest in the same session. 


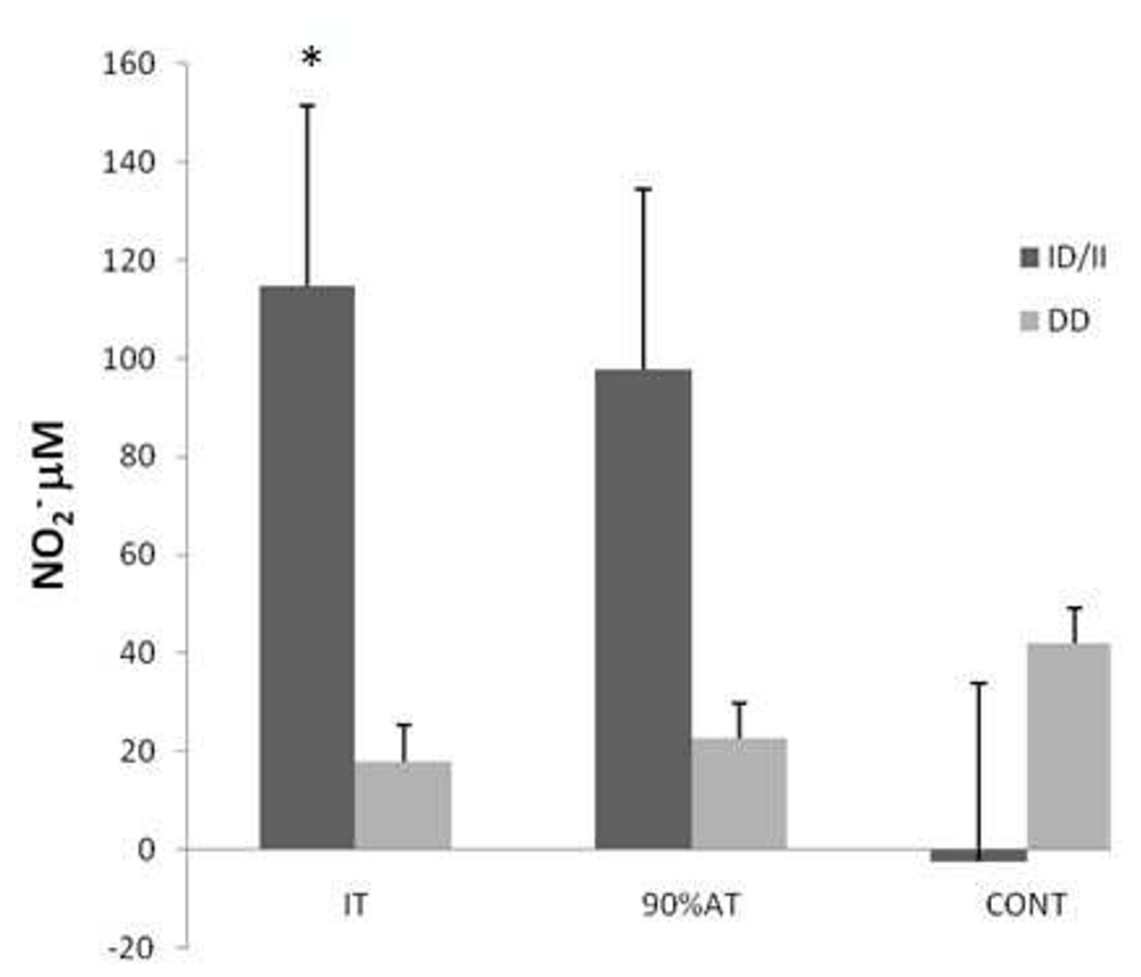

Figure 1 Mean $\left( \pm\right.$ SEM) delta variation of $\mathrm{NO}_{2}^{-}$(nitrite) for IT (Incremental test), 90\% AT (90\% of anaerobic threshold) and CONT (control) sessions performed by ID/II $(\mathbf{n}=\mathbf{1 8})$ and DD $(\mathbf{n}=\mathbf{1 0})$ genotypes of ACE gene. ${ }^{*} p<0.05$ in relation to D/D group on IT session.

vasoconstriction and also enhancing water and sodium reabsorption by the kidneys, increasing blood volume and blood pressure.

The trends of a higher exercise intensity to be more effective on inducing PEH (table 2) are in accordance to former results in our laboratory, but on individuals with type-2 diabetes [11]. The possible role of exercise intensity on the present study was demonstrated for the results of $\mathrm{NO}$ release as well (table 3). The $\mathrm{NO}_{2}{ }^{-}$results of this study reinforce the important role of the $\mathrm{NO}$ on reducing $\mathrm{BP}$, as already demonstrated by other authors $[2,42,48]$.

Nevertheless, Lauer et al. (2008) [42] showed that elderly, when compared to youngsters, has endothelial dysfunction being harder in increase plasmatic $\mathrm{NO}_{2}{ }^{-}$in response to exercise. However, it was interesting to demonstrate in our research that in elderly population the ability to increase $\mathrm{NO}_{2}{ }^{-}$may be intensity-dependent, and may be associated to genetic characteristics with the DD group not presenting significant changes in $\mathrm{NO}_{2}{ }^{-}$ and these findings together are the main contribution of the present study.

Tanriverdi et al. (2005) [49] verified that flux mediated dilation response in athletes presenting that II, was higher than ID and DD genotypes, being the homozygote $\mathrm{D}$ with the worst response to flux mediated dilation, what corroborates with our results (no PEH and lower $\mathrm{NO}_{2}{ }^{-}$release for the DD group).

The increased liberation of the $\mathrm{NO}_{2}{ }^{-}$after exercise sessions may occurs due to shear stress in the blood vessels what stimulates the endothelial NO formation [50,51]. The fact that $\mathrm{NO}_{2}{ }^{-}$being significantly higher only after the IT session, on the I/D - I/I group, may also be due to exercise at higher intensity to promote a more significant shear stress [52], even for elderly that may be predispose to endothelial dysfunction and low NO release $[42,53,54]$.

The study limitations were not measuring the endothelial nitric oxide synthase (eNOS) what could represent the endothelial dependent activity and, consequently, a possible PEH. However, some authors [31-33] verified that the $\mathrm{NO}_{2}{ }^{-}$in saliva predicts the plasmatic $\mathrm{NO}_{2}{ }^{-}$concentration that is one of better eNOS activity indexes [55]. Another limitation of this study was the lack of ACE measurement in the elderly participants; however some authors [24,25] observed higher values of this activity with homozygote $\mathrm{D}$ when compared to other ACE genotypes.

\section{Conclusion}

The II/ID individuals, but not the DD group, presented PEH for SBP in both experimental exercise sessions. 
However, both groups had a protective effect of aerobic exercise on preventing the increase of DBP and MAP during post-exercise period. The endothelial responses of NO to exercise were only presented by the ID/II ACE genotype group and, similarly to $\mathrm{PEH}$, seemed to be influenced by exercise intensity.

Therefore, the ACE genotype seems exert a role in the $\mathrm{NO}$ release and BP response during post-exercise recovery in elderly women. Any extrapolation of these results to other gender or age strata requires caution.

\section{List of Abbreviations}

Angiotensin converting enzyme (ACE), nitric oxide (NO), blood pressure (BP), systemic arterial hypertension (SAH), post-exercise hypotension (PEH), insertion/deletion (I/D), angiotensin II (ANG II), renin-angiotensin system (RAS), nitrite $\left(\mathrm{NO}_{2}{ }^{-}\right)$, resting before exercise (or control) in all testing days (PRE), immediately after exercise (IAE), blood lactate concentration ([Lac]), maximal incremental test (IT), rate of perceived exertion (RPE), ventilation $(\mathrm{VE})$, oxygen uptake $\left(\mathrm{VO}_{2}\right)$, carbon dioxide production $\left(\mathrm{VCO}_{2}\right)$, ventilatory equivalent for oxygen $\left(\mathrm{VE} / \mathrm{NO}_{2}\right)$, dioxide carbon $\left(\mathrm{VE} / \mathrm{NCO}_{2}\right)$.

\section{Acknowledgements}

Conselho Nacional de Desenvolvimento Cientifico (CNPq) and Coordenação de Aperfeiçoamento de Pessoal de Nível Superior (CAPES).

\section{Author details}

'Programa de Pós-graduação em Educação Física e Saúde, Universidade Católica de Brasília - UCB, Brasília-DF, Brazil. ${ }^{2}$ Centro Universitário do Planalto de Araxá - UNIARAXÀ; Araxá-MG, Brazil. ${ }^{3}$ Universidade Federal do Vale do São Francisco -UNIVASF- Petrolina-PE, Brazil. ${ }^{4}$ Faculdade de Educação Física do Centro Anhanguera Educacional, Taguatinga-DF, Brazil. ${ }^{5}$ Faculdade de Educação Física do Centro Universitário - UNIRG -, Gurupi-TO, Brazil. ${ }^{6}$ Instituto de Genética e Bioquímica da Universidade Federal de Uberlândia UFU, Uberlândia-MG, Brazil. ${ }^{7}$ Programa de Pós-Graduação em Ciências Médicas e Programa de Pós -graduação em Ciências da Saúde, Universidade de Brasília - UnB, Brasília-DF, Brazil.

\section{Authors' contributions}

HAPS, SRM, CBS, CSGC and HGS participated in the design of the study. HAPS, SRM, CBS, WBN and VNO performed the data collection. HAPS, SRM performed the statistical analysis. HAPS, SRM, MMS, RYA, FSE, OTN and HGS wrote the manuscript. All authors read and approved the final manuscript.

\section{Competing interests}

The authors declare that they have no competing interests.

Received: 19 May 2011 Accepted: 2 December 2011

Published: 2 December 2011

\section{References}

1. O'Brien E, Beevers G, Lip GYH: ABC of hypertension: Blood pressure measurement. BMJ 2001, 322:1110-1114.

2. Chobanian AV, Bakris GL, Black HR, Cushman WC, Green LA, Izzo JL Jr, Jones DW, Materson BJ, Oparil S, Wright JT Jr, Roccella EJ: The Seventh Report of the Joint National Committee on Prevention, Detection, Evaluation, and Treatment of High Blood Pressure: The JNC 7 Report. JAMA 2003, 289:2560-2571.

3. Kaplan N: Clinical Hypertension. Baltimore Williams and Wilkins , 51990

4. Perticone F, Ceravolo R, Pujia A, Ventura G, lacopino S, Scozzafava A, Ferraro A, Chello M, Mastroroberto P, Verdecchia P, Schillaci G: Prognostic significance of endothelial dysfunction in hypertensive patients. Circulation 2001, 104(2):191-196.

5. Galetta F, Franzoni F, Plantinga Y, Ghiadoni L, Rossi M, Prattichizzo F, Carpi A, Taddei S, Santoro G: Ambulatory blood pressure monitoring and endothelium-dependent vasodilation in the elderly athletes. Biomed Pharmacother 2006, 60(8):443-447.
6. American College of Sports Medicine: Physical activity, physical fitness and hypertension. Med and Sci in Sports and Exerc 1993, 25:i-X.

7. MacDonald JR, MacDougall JD, Hogben CD: The effects of exercise intensity on post exercise hypotension. J Hum Hypertens 1999, 13:527-531.

8. Halliwill JR, Minson CT, Joyner MJ: Effect of systemic nitric oxide synthase inhibition on postexercise hypotension in humans. J Appl Physiol 2000, 89:1830-1836.

9. Halliwill JR: Mechanisms and Clinical Implications of Post-exercise Hypotension in Humans. Exerc Sport Sci Rev 2001, 29(2):65-70.

10. Pescatello LS, Turner D, Rodriguez N, Blanchard BE, Tsongalis GJ, Maresh CM, Duffy V, Thompson PD: Dietary calcium intake and Renin Angiotensin System polymorphisms alter the blood pressure response to aerobic exercise: a randomized control design. Nutr \& Metabolism 2007, 4(1), 1743-7075-4-1.

11. Lima LC, Assis GV, Hiyane W, Almeida WS, Arsa G, Baldissera V, Campbell CS, Simões HG: Hypotensive effects of exercise performed around anaerobic threshold in type 2 diabetic patients. Diabetes Res Clin Pract 2008, 81(2):216-222.

12. Jones $\mathrm{H}$, George K, Edwards B, Atkinson G: Exercise intensity and blood pressure during sleep. Int J Sports Med 2009, 30(2):94-99.

13. Simões GC, Moreira SR, Kushinick MR, Simões HG, Campbell CSG: Postresistance exercise blood pressure reduction is influenced by exercise intensity in healthy individuals and in those with type-2 diabetes. J Strength Cond Res 2010.

14. Wallace JP, Bogle PG, King BA, Krasnoff JB, Jastremski CA: The magnitude and duration of ambulatory blood pressure reduction following acute exercise. J Hum Hypertens 1999, 13(6):361-366.

15. Mota MR, Pardono E, Lima LCJ, Gisela A, Bottaro M, Campbell CSG, Simões HG: Hypotensive effects of treadmill running and resistance exercise during the daily work of hypertensive subjects. J Strength Cond Res 2009, 23(8):2331-2338.

16. Lüscher TF, Corti R: Flow: the signal of life. Circ Res 2004, 95(8):749-751.

17. Nathan C, Xie QW: Regulation of the biosynthesis of nitric oxide. J Biol Chem 1994, 269:13725-13728.

18. Augeri AL, Tsongalis GJ, Van Heest JL, Maresh CM, Thompson PD, Pescatello LS: The endothelial nitric oxide synthase $-786 \mathrm{~T}>\mathrm{C}$ polymorphism and the exercise-induced blood pressure and nitric oxide responses among men with elevated blood pressure. Atherosclerosis 2009, 204(2)::28-34

19. Hagberg JM, Park JJ, Brown MD: The role of exercise training in the treatment of hypertension: an update. Sports Med 2000, 30:193-206.

20. Williams AG, Rayson MP, Jubb M, World M, Woods DR, Hayward M, Martin J, Humphries SE, Montgomery HE: The ACE gene and muscle performance. Nature 2000, 403:614

21. Saeed M, Saleheen D, Siddiqui S, Khan A, Butt ZA, Frossard PM: Association of angiotensin converting enzyme gene polymorphisms with left ventricular hypertrophy. Hypertens Res 2005, 28(4)

22. Sayed-Tabatabaei FA, Oostra BA, Isaacs A, van Duijn CM, Witteman JCM: ACE polymorphisms. Review, Circ Res 2006, 98(9):1123-1133.

23. Kim K: Association of angiotensin-converting enzyme insertion/deletion polymorphism with obesity, cardiovascular risk factors and exercisemediated changes in Korean women. Eur J Appl Physiol 2009, 105:879-887.

24. Rigat B, Hubert C, Alhenc-Gelas F, Cambien F, Corvol P, Soubrier F: An insertion/deletion polymorphism in the angiotensin l-converting enzyme gene accounting for half the variance of serum enzyme levels. J Clin Invest 1990, 86(4):1343-1346.

25. Alvarez R, Terrados N, Ortolano R, Iglesias-Cubero G, Reguero J, Batalla A, Jones DW, Materson BJ, Oparil S, Wright JT Jr, Roccella EJ: Genetic variation in the renin-angiotensin system and athletic performance. Eur J Appl Physiol 2000, 82:117-120.

26. Jalil JE, Córdova S, Ocaranza M, Schumacher E, Braun S, Chamorro G, Fardella C, Lavandero S: Angiotensin I-converting enzyme insertion/ deletion polymorphism and adrenergic response to exercise in hypertensive patients. Med Sci Monit 2002, 8(8):566-571.

27. Moraes MR, Bacurau RPF, Ramalho JDS, Reis FC, Casarini DE, Chagas JR, Oliveira V, Higa EM, Abdalla DS, Pesquero JL, Pesquero JB, Araujo RC: Increase in kinins on post-exercise hypotension in normotensive and hypertensive volunteers. Biol Chem 2007, 388:533-540.

28. Taguchi T, Kishikawa H, Motoshima H, Sakai K, Nishiyama T, Yoshizato K, Shirakami A, Toyonaga T, Shirotani T, Araki E, Shichiri M: Involvement of bradykinin in acute exercise-induced increase of glucose uptake and 
GLUT-4 translocation in skeletal muscle: studies in normal and diabetic humans and rats. Metabolism 2000, 49:920-930.

29. IV Brazilian Guidelines in Arterial Hypertension Work Groups: IV Brazilian guidelines in arterial hypertension. Ara Bras Cardiol 2004, 82(S4):7-22.

30. Moraes CF, Souza ER, Souza VC, Medeiros EF, Gonçalves TF, Toledo JO, Karnikowski M, Gomes L, Karnikowski MG, Córdova C, Nóbrega OT: A common polymorphism in the renin angiotensin system is associated with differential outcome of antihypertensive pharmacotherapy prescribed to Brazilian older women. Clin Chim Acta 2008, 396(1-2):70-75.

31. Miyado T, Tanaka Y, Nagai H, Takeda S, Saito K, Fukushi K, Yoshida Y, Wakida S, Niki E: Simultaneous determination of nitrate and nitrite in biological fluids by capillary electrophoresis and preliminary study on their determination by microchip capillary electrophoresis. J Chromatogr A 2004, 1051:185-191.

32. Tanaka $H$, Dinenno FA, Monahan KD, Clevenger CM, DeSouza CA, Seals DR: Aging, habitual exercise, and dynamic arterial compliance. Circulation 2000, 102:1270-1275.

33. Gáspár A, Juhász P, Bágyi K: Application of capillary zone electrophoresis to the analysis and to a stability study of nitrite and nitrate in saliva. $J$ Chromatogr 2005, 1065:327-331.

34. Marre M, Jeunemaitre X, Gallois Y, Rodie M, Chatellier G, Sert C, Dusselier L, Kahal Z, Chaillous L, Halimi S, Muller A, Sackmann H, Bauduceau B, Bled F, Passa P, Alhenc-Gelas F: Contribution of genetic polymorphism in the renin-angiotensin system to the development of renal complications in insulin-dependent diabetes: Genetique de la Nephropathie Diabetique (GENEDIAB) study group. J Clin Invest 1997, 99:1585-1595.

35. Córdova C, Silva VC, Moraes CF, Simões HG, Nóbrega OT: Acute exercise performed close to the anaerobic threshold improves cognitive performance in elderly females. Braz J Med Biol Res 2009, 42:458-464

36. Borg GAV: Psycophysical bases of perceived exertion. Med Sci Sports Exerc 1982, 14:377-381.

37. Jones A, Woods DR: Skeletal muscle RAS and exercise performance. Intern J Biochem Cell Biol 2003, 35:855-866.

38. Pescatello LS, Kostek MA, Gordish-Dressman H, Thompson PD, Seip RL, Price TB, Angelopoulos TJ, Clarkson PM, Gordon PM, Moyna NM, Visich PS, Zoeller RF, Devaney JM, Hoffman EP: ACE ID genotype and the muscle strength and size response to unilateral resistance training. Med Sci Sports Exerc 2006, 38(6):1074-1081.

39. Blanchard BE, Tsongalis GJ, Guidry MA, LaBelle LA, Poulin M, Taylor AL, Maresh CM, Devaney J, Thompson PD, Pescatello LS: RAAS polymorphisms alter the acute blood pressure response to aerobic exercise among men with hypertension. Eur J Appl Physiol 2006, 97(1):26-33.

40. Fornage $\mathrm{M}$, Amos $\mathrm{Cl}$, Kardia S, Sing CF, Turner ST, Boerwinkle E: Variation in the region of the angiotension-converting enzyme gene influences interindividual differences in blood pressure levels in young white males. Circulation 1998, 97:1773-1779.

41. O'Donnell CJ, Lindpaintner K, Larson MG, Rao VS, Ordovas JM, Schaefer EJ, et al: Evidence for association and genetic linkage of the angiotensinconverting enzyme locus with hypertension and blood pressure in men but not in women in the Framigham Heart Study. Circulation 1998, 97:1766-1772.

42. Lauer T, Heiss C, Balzer J, Kehmeier E, Mangold S, Levendecker T, Rottler J, Meyer C, Merx MW, Kelm M, Rassaf T: Age-depend endothelial dysfunction is associated to failure to increase plasma nitrite in response to exercise. Bas Res Cardiol 2008, 103:291-297.

43. Zimmerman RS, Frohlich ED: Stress and hypertension. J Hypertens 1990, 8 S103-S107.

44. MacDonald JR, Hogben CD, Tarnopolsky MA, MacDougall JD: Post exercise hypotension is sustained during subsequent bouts of mild exercise and simulated activities of daily living. J Hum Hypertens 2001, 15:567-71.

45. Busjahn A, Voss $\mathrm{A}$, Knoblauch $\mathrm{H}$, Knoblauch $\mathrm{M}$, Jeschke $\mathrm{E}$, Wessel $\mathrm{N}$, Bohlender J, McCarron J, Faulhaber HD, Schuster H, Dietz R, Luft FC: Angiotensin-converting enzyme and angiotensinogen gene polymorphisms and heart rate variability in twins. Am J Cardiol 1998, 81(6):755-60.

46. Jalil JE, Córdova S, Ocaranza M, Schumacher E, Braun S, Chamorro G, Fardella C, Lavandero S: Angiotensin I-converting enzyme insertion/ deletion polymorphism and adrenergic response to exercise in hypertensive patients. Med Sci Monit 2002, 8(8):CR566-71.

47. Todd GP, Chadwick IG, Higgins KS, Yeo WW, Jackson PR, Ramsay LE: Relation between changes in blood pressure and serum ACE activity after a single dose of enalapril and ACE genotype inhealthy subjects. $\mathrm{Br}$ J Clin Pharmacol 1995, 39(2):131-4.

48. Rees DD, Palmer RM, Hodson HF, Moncada S: A specific inhibitor of nitric oxide formation from L-Arginine attenuates endothelial-dependent relaxation. Br J Pharmacol 1989, 96:418-424.

49. Tanriverdi $\mathrm{H}$, et al: Improved endothelium dependent vasodilation in endurance athletes and its relation with ACE I/D polymorphism. Circ J 2005, 69(9):1105-1110.

50. Cooke JP, Rossitch E, Andon NA, Loscalzo J, Dzau VJ: Flow activates an endothelial potassium channel to release an endogenous nitrovasodilator. J Clin Invest 1991, 88:1663-1667.

51. Miller VM, Burnett JC Jr: Modulation of NO and endothelin by chronic increases in blood flow in canine femoral arteries. Am J Physiol 1992, 263:103-108

52. Van Citters RL, Franklin D: Cardiovascular performance of Alaska sled dogs during exercise. Circ Res 1969, 24:33-42.

53. Turcato S, Turnbull L, Wang GY, Honbo N, Simpson PC, Karliner JS, Baker AJ: Ischemic preconditioning depends on age and gender. Basic Res Cardiol 2006, 101:235-243.

54. Weinsaft JW, Edelberg JM: Aging-associated changes in vascular activity: a potential link to geriatric cardiovascular disease. Am J Geriatr Cardiol 2001, 10:348-354.

55. Lauer T, Priek M, Rassaf T, Strauer BE, Deussen A, Feelisch M, Kelm M: Plasma nitrite rather than nitrate reflects regional endothelial nitric oxide synthase activity but lacks intrinsic vasodilator action. Proceedings of the National Academy of Science of the USA 2001, 23:12814-12819.

\section{Pre-publication history}

The pre-publication history for this paper can be accessed here: http://www.biomedcentral.com/1471-2261/11/71/prepub

doi:10.1186/1471-2261-11-71

Cite this article as: Santana et al:: The higher exercise intensity and the presence of allele I of ACE gene elicit a higher post-exercise blood pressure reduction and nitric oxide release in elderly women: an experimental study. BMC Cardiovascular Disorders 2011 11:71.

\section{Submit your next manuscript to BioMed Central and take full advantage of:}

- Convenient online submission

- Thorough peer review

- No space constraints or color figure charges

- Immediate publication on acceptance

- Inclusion in PubMed, CAS, Scopus and Google Scholar

- Research which is freely available for redistribution

Submit your manuscript at www.biomedcentral.com/submit
C BioMed Central 